\title{
The Availability of Critical Thinking Skills in the English Course for First Intermediate Grade: Analytical Study
}

\section{Dr. Maha Affat Aldoghmi}

Associate professor at curricula and instruction deptrtment, faculty of Education, Al-Jouf University

\section{Abstract:}

he aim of this study is to identify critical thinking skills
required for middle school students, as well as the
availability of critical thinking skills in the English language course for the first intermediate grade. The researcher used the descriptive analytical method, where she analyzed the content of the English course for the first intermediate grade by a designed content analysis form that included five main skills: Recognition of assumptions, interpretation, deduction skill, and inference skill. Findings revealed "variance" in the percentages of critical thinking main skills and subskills in the first intermediate grade English course. Findings also revealed that the English language course lacks a balance between the main skills of critical thinking and sub-skills, especially as the sub-skills complement the main skills. However importance sub-skills of critical thinking have, they do not achieve learning critical thinking required to be learned.

Keywords: Critical Thinking Skills - English Course - First Intermediate.

\section{Introduction:}

A complex way of life has been imposed by the modern changes in the educational field. The simple learner -with his ideas and vision of the future- is no longer able to neither deal with new knowledge nor keep pace with rapid events. Modern life, according to the characteristics of globalization, needs the independent learner- in his opinion and thinking- to be able to face different problems, accurately examine them, and draw solutions to make the appropriate decisions based on clarity. 
This way of life has called for a modern scientific method depends on mental thinking and logical reasoning. Thus, the teaching of thinking has emerged as a strategic goal in all global education systems, and demands have been made for the design of plans and programs as well as strategies for developing thinking skills in general for education. Efforts to educate thinking skills have intensified since the 1970s and one of the most prominent trends in the development of education has been the teaching of thinking and its use as a strategy for education (Al Nafea, 2008).

The remarkable increase in knowledge and the complexity of its branches have created a kind of challenges in face of curriculum scientists and those who are interested in education. Cognition has emerged as one of the most important pillars and foundations of the curriculum designing processes.

The modern curriculum came to focus on building the personality of the student; it was about meeting his needs, interests, attitudes, and building his abilities so that he would be able to deal with life situations with wisdom and insight. The modern curriculum has been defined as: "A set of educational experiences provided by school for pupils with the aim of helping them to grow and to modify behavior" (Al Wakil and Mufti, 2005,41).

The changes in the educational field have greatly affected all aspects of life. Since education in all global systems is the most influential means on the individual, and curricula are the tools to make that effect, the educational institutions were held responsible for preparing the learner for a modern life that makes him able to face the challenges and to be ready for them. So, the curricula have to give priority to the twenty-first century skills. Critical thinking and creative thinking are the most important skills of this era. The importance of analysis, deduction and exploration has emerged as one of the most 
important factors in confronting dogmatism that dominates the mental and intellectual processes. Content analysis reveals the ability of educational experiences to build a learner mentality. (Al Rajhi, 2008) (Al-Rajhi, 2008).

The development of the educational system, including teaching methods, is a national demand and a strategic goal imposed by cognitive challenges, to improve man-thinking and enable him to actively deal with the developing science. English language is one of the important channels of communication in various aspects and areas of life. Saudi Arabia is high aware of the importance of teaching English from the sixth grade in public schools in 1426 A.H.

In general, the curricula have basic foundations that are taken into consideration in the planning, evaluation and development processes, including: cognitive, social, psychological and philosophical principles. Curriculums - in different fields- have a fundamental role to play in preserving the identity of culture. This importance is multiplied in English language courses.

English language curricula, like other curricula of the Ministry of Education, have undergone many stages of evaluation and development, such as the development of English curriculum (1437AH). Curriculum development -in the overall project- was intended to develop the critical thinking skills among learners (Tatweer, 1437H). Then, came the Kingdom's Vision (2030), which has called for the existence of modern curricula that simulate the requirements of cognitive life.

The circle of interest in thinking skills has expanded until new concepts related to critical thinking have emerged. Developing thinking skills helps to deep understanding of knowledge, and the process of thinking requires the use of mental skills to reach the highest degree of clarity and accuracy. There were many definitions and perceptions about the concept 
of critical thinking according to different schools and their multiplicity, which later expanded in interpretation and clarification of different aspects of critical thinking.

\section{Problem of the study:}

One of the most important challenges facing education, monitored by the National Transformation Program (2020), is the lack of personal and critical thinking skills among students. So, a need to develop curricula to meet the requirements of modern life has emerged. English language course -for the first intermediate grade- is one of the courses that need to be developed and analyzed to be more responsive to the needs of the students at this stage, especially as it is characterized by tendency toward independence and seeking knowledge. It is also considered a transitional stage in which the personal characteristics of students mature.

In line with The Kingdom's Vision (2030), the researcher considered the importance of analyzing English language course, which is taught for the first intermediate grade in Saudi Arabia. The study attempts to answer the following questions:

1. What critical thinking skills are needed for middle school students?

2. To what extent do critical thinking skills -in English language for the first intermediate grade - exist?

\section{Goals of the study:}

The study aims to identify the following:

1- Critical thinking skills required for middle school students.

2 - The availability of critical thinking skills in English language for the first intermediate grade.

\section{The importance of study:}

The importance of this study stems from the importance of the requirements of the modern age, and in line with modern trends in building learners' personality to be more adapted to 
situations and problems, and more flexible and objective in dealing with them. Learning critical thinking skills can help reduce scientific weakness by empowering students from these skills. The Kingdom's Vision (2030) pays attention to students' personality to be more responsive to the requirements of modern life, and focuses on the development of critical thinking skills as one of the most important aspects that makes the wise mind.

\section{Determination of the study:}

- Objective determinations: including definitions of critical thinking skills and their availability in English language for the first intermediate grade in public schools in Saudi Arabia.

- Time determinations: This study will be conducted during the second semester of the academic year 1440 AH / 2019 AD.

\section{Methodology of the study:}

The analytical descriptive method was used, which is suitable for the study goals.

\section{Population of the Study:}

English language course for the first grade in the academic year $1440 \mathrm{AH}$.

\section{Terminology of study:}

\section{Critical Thinking:}

Edward Glaser proposed that critical thinking is an attitude of being disposed to consider in a thoughtful way the problems and subjects that come within the range of one's experiences, and knowledge of the methods of logical inquiry and reasoning.

Operationally, critical thinking can be defined as a mental process and a skill demonstrate that the ability to reflect, analyze and solve problems in a scientific, logical way is based on deduction, inference and argument; so that one can make a decision about the problem and judge it with credibility and clarity. 


\section{English language for the first intermediate grade course:}

It is the scholastic curriculum with all its elements from the objectives to the evaluation, and scheduled to be taught to the first intermediate grade students in public schools in Saudi Arabia.

\section{Intermediate stage:}

the second stage in the educational ladder, as it is an independent educational stage after the primary stage, and precedes the secondary stage. The learner joins it at the age of twelve years, which is consistent with the psychological and physical characteristics of the student at the beginning of adolescence.

\section{The education policy in Saudi Arabia has defined the concept of this stage (1416 A.H) as:}

"a general cultural stage that aims to educate the young person in a comprehensive Islamic education in many aspects: faith, mind, body, and moral, taking into consideration the characteristics of this stage, and it participates in the achievement of the general goals of education. "

\section{The goals of this stage includes:}

empowering the Islamic faith in students; making it as a controller of the behavior, developing the love, piety and fear of Allah in heart, providing experiences and knowledge appropriate to this age to familiarize the general principles and basic principles of culture and science, encouraging seeking knowledge, and developing mental abilities and various skills. It also aims to strengthen the awareness of the student to know according to his age - how to face misleading rumors, destructive doctrines, and extraneous principles.

It is noted that these goals stem from the teachings of our Islamic religion, and are commensurate with the characteristics of the growth at this stage in which the student "can learn any subject and acquire any skill, provided that it is presented correctly" (Saleh, 1992). 


\section{Literature and previous studies:}

The ability - to deal with information in a scientific way and to identify the components of the information, and then identify its source to formulate it clearly and present it scientifically- is one of the most important characteristics of critical thinking. It enables persons to form correlations of information with other similar information in other situations as well as dealing with the information in depth. So what is critical thinking? What are the most critical thinking skills needed for middle school students? What are the characteristics of the growth at this stage?

\section{First: The most important concepts that explain and clarify critical thinking:}

- Critical thinking aims to analyze and evaluate to distinguish accepted belief in the light of mental criteria (Bagmil, 2011).

- The ability to manage thinking and using mental skills to reach a result or thinking characterized by accuracy, flexibility, effectiveness, logical and clarity (Abdel Moati, 2005).

- The process of taking decisions and judgments by distinguishing between facts and opinions and examining the hypotheses to assess the truth and express them objectively (Al-Qutaiti, 2016).

\section{Second: Critical Thinking Skills Needed for Middle School Students}

Critical thinking process requires higher skills of analysis and devising solutions. Critical thinking skill lies in the ability of making the right decision after the processes of examination, analysis and discrimination and then infer the appropriate solutions.

Psychologists and education scholars have paid great interest to the process of critical thinking. It helps the learner to cope with the cognitive flow and identify the facts in preparation for acceptance or rejection in the light of evidence. Consequently, developing these skills has become one of the most important 
educational goals that educational institutions -with different positions- seek to achieve.

Critical thinking skills are important because they are associated with life skills, with individual and social implications. For students, Critical thinking skills help them to understand deeply and achieve cognitive mastery. They also, lead the learner to independent intellectual personality, and increase his selfconfidence that encourage him to initiate research and inquiry until reaching the truth and can judge it without being influenced by others. Thus, the learner is more positive and more interactive and the result is the improvement of his achievement level (Saho, 2017).

One of the most popular models of critical thinking skills is Watson Glaser, who has divided critical thinking skills into several subdivisions (Fitcher, 2009):

- The first skill: Recognition of assumption: it refers to learners' ability to learn assumptions involved in a particular topic, and this skill means that the learner has the ability to examine data on a subject, and distinguish between truth and opinion.

- The second skill: Interpretation: it refers to learners' ability to derive a certain result from the assumed facts, and to draw meaning or explain the meanings, and identify the problem and recognize the logical explanations.

- The third skill: Deduction: it refers to learners' ability to draw partial results in the light of general rules and principles. It is a skill that enables learners to identify the relationships between the presented facts, and therefore have the skill to judge these facts and derived facts.

- The fourth skill: Inference: it refers to learners' ability to reach different conclusions of accuracy and clarity in the light of facts and information. It is a skill that demonstrates the learner's ability 
to distinguish between right from wrong of particular data provided.

- The fifth skill: Evaluation of arguments it refers to a skill that enables the learner to distinguish between strong from weak arguments, and to judge the credibility of phrases according to personal experiences and perceptions, and accept or reject the idea, and distinguish between primary and secondary sources.

\section{Third: Characteristics of intermediate stage development:}

Middle school education in Saudi Arabia aims to raise the level and degree of integrated growth of students in all aspects: spiritual, physical, mental and emotional. Educational institutions have been keen to prepare them for working life in the environment where they live. The intermediate stage is a decisive stage in the lives of students, psychologists called this stage "adolescence", and it can be defined as "that mysterious period of life, which extends from the end of childhood to the beginning of the emergence of the characteristics of femininity and masculinity" (Saleh, 193, 1992).

Zahran (2005) defined it as "a period of time in individuals' life, characterized by physical and physiological changes, which take place under certain social pressures, Giving this stage distinct psychological features. the cultural conditions -in some cultures- help to distinguish this stage."

The intermediate stage is a transitional stage between the primary and secondary stages. It represents the end of childhood and the beginning of adolescence, in which the personal and social characteristics of students are evident. In order to improve pupils' learning at this important stage of growth, and achieve them a comprehensive and integrated growth. Among the most important characteristics of growth that characterize this stage (Zahran, 2005, and Zaki Saleh, 1992):

1. Physical development: Physical development is characterized by the following: rapid growth, increased muscle growth, and 
physical strength in general. Differences in muscle strength are most pronounced between females and males. The length increases rapidly, the shoulders widen and the circumference of the buttocks, and the length of legs; which leads to an increase in length.

2. Mental development: It refers to changes in mental performance in quantity and quality", which goes from simple to complex processes. The characteristics of mental development are concentrated in the perception of abstract concepts, relationships, moral principles and values. Attention, listening, and cognition develop faster than in childhood. The ability to imagine, and to daydream, is also increasing. Individual differences are also evident at this stage, and the difference in the degree of general mental ability is shown. The most important characteristic of this stage is the development of tendencies and interests, and the emergence of adolescent interest in the future of education and career, teenager also tends to think critically, does not accept facts without evidence.

3. Emotional development: changes in the emotions of adolescents and in their responses to stimuli around them. Emotional development at this stage includes observation and individual differences that make a teenager extremely sensitive, as well as emotional fluctuations in the behavior because they behave like adults at times, young at other times, and keen to create an autonomous identity, and achieve emotional independence. They also observe the vast, fertile imagination and daydream.

4. Social development: Clarity of the relationship between the individual and the environment. The most prominent characteristics of social growth include: independence, selfreliance, social independence, sense of command and control, rejection of power forms, and non-acceptance of adult directions. The adolescent is increasingly inclined to belong to a group of friends.

\section{Related studies}

Al-Zahrani (2018): This study aimed to explore the extent to what first graders at middle school achieved critical thinking skills in mathematics. The study used the descriptive method. A 
test was designed to measure the level of students in four critical thinking skills: prioritization, sequencing, interpretation, and deduction. The study found that the ability of critical thinking skills came with a medium degree (35.66).

Al-Dulaimi and Al-Huwaimel (2017): This study aimed to identify the availability of critical thinking skills in the Arabic language textbook (communication skills) for the eighth grade in Jordan. A descriptive analytical method was used, and a tool for measuring critical thinking skills was prepared, dealing with five main skills (deduction, evaluation, interpretation, recognition of assumptions, and analysis). The study findings revealed "variance" in the distribution of critical thinking skills in the Arabic language book; where prose classes contain more critical thinking skills than poetry lessons.

Nawaflah (2015): This study aimed to determine the availability of critical thinking skills in the content of the chemistry questions of the ninth and tenth grades in Jordan. An analysis form consisting of critical thinking skills according to the classification of the content of the questions was used. Findings showed that there are three main skills in the content of the course questions: interpretation, analysis, and explanation. Three other key skills came poorly and were not adequately available: Inference, evaluation, and self-organization. Six subskills were found to be sufficient in the content of chemistry textbooks out of 16 skills: classification, extraction of meaning, clarification of meaning, examination of ideas, acknowledgment of results, and presentation of arguments.

Mukhtar (2014): This study aimed to determine the availability of scientific thinking skills and critical thinking skills in the content of science courses, as well as to determine the level of performance of first grade secondary students in tests of scientific thinking skills and critical thinking skills compared to the educational level acceptable. The study used different tools: test and analysis content card of science course, the sample of 
the study was (503) students, the study revealed the following findings: The science courses are in need to development, since they - in current situation- do not meet the development of scientific thinking skills and critical thinking.

Abu Mahadi (2011): This study aimed to identify the critical thinking skills that should be available in the physics curriculum for secondary school. Participants were (400) students. The researcher used the descriptive analytical method, and adopted several tools, including: list of critical thinking skills, content analysis form, and a test. The most important findings of the study: Deduction skill obtained (32.7\%), while recognition of assumptions skill obtained (20.8\%), and evaluation of arguments skill obtained (19.7\%), lastly, Inference skills obtained (15.3\%).

Almabdel (2010): This study aimed to explore the relationship between the positive components of the classroom environment and critical thinking skills in secondary school students in Riyadh. The Positive Component Scale for the Classroom Environment, based on the Murray Theory for Environmental Stress and Psychological Needs, was used. The WGCTSF was used to measure critical thinking. The sample consisted of (1212) students from the secondary stage. The study findings revealed a positive and statistically significant relationship between the positive components of the classroom and critical thinking skills.

Al-mahmos (2009): This study aimed to identify the skills of critical thinking: (deduction, distinguishing hypotheses, drawing conclusions, interpretation, and evaluating arguments), in the syntax book for the third grade in Saudi Arabia. The study used the descriptive analytical method. Study population consisted of the syntax book for the class mentioned. The most important findings of the study: There are indications that most of the critical thinking skills are neglected in the course of study, as well as the lack of educational aids to develop critical thinking, the use of traditional methods, the authors of the course rely on narrative without including questions that provoke pupils' 
thinking to help them draw conclusions, evaluate the arguments and distinguish hypotheses.

\section{Comments on the previous studies:}

The previous studies agreed with the current study on the subject of "critical thinking" and clarified its importance in building the personality of the student. It also agreed with the methodology used in the current research, the descriptive analytical method. The following studies Al-Dulaimi and AlHuwaimel (2017), Mukhtar (2014) and Geek (2009) also agreed in the study community, which analyzed the content of the book according to the specialization of these books. It also agreed with the study of Nawafla (2015) and the study of Abu Mahdi (2011) in terms of subject and objectives and differed in terms of the course of the study.

The present study differed with regard to the purpose of the study from each of the following studies: Al-Zahrani (2018) and Al-Mu'adil (2010); It dealt with critical thinking and its relationship with both the student and the classroom environment.

The researcher has benefited from the previous studies in determining the critical thinking skills included in the study population, formulating the elements of the analysis of the content of the book, and in selecting the appropriate statistical methods and treatments, in addition to the scientific value gained by the researcher in terms of presentation and discussion, in order to reach findings meets the purposes of the present study.

\section{Methodology}

\section{Study population:}

The current study population consists of the English language course (Student's Book and Work Book) for the first intermediate grade in the stages of public education, which is taught during the academic year 1439/1440 AH. The sample of the study is the book and the activities included in the course. The course consists of (10) units, each unit includes (4) lessons, in (85) pages shown in table (1). 
Table (1): The study population and its sample from the first grade English language course

\begin{tabular}{|c|c|c|c|}
\hline Unit title & Lesson title & Pages & Activity \& Page \\
\hline \multirow[t]{4}{*}{ NEW FRIENDS } & It's nice to meet you & 6-7 & 1-6.P.88-89 \\
\hline & Meet the Family & $8-9$ & 1-5.P.90-91 \\
\hline & This is my cousion & 10-11 & 1-5.P.92-93 \\
\hline & REVIEW & $12-13$ & \\
\hline \multirow[t]{4}{*}{ MY THINGS } & What's he wearing? & 14-15 & 1-5.P.94-95 \\
\hline & My Father's car & 16-17 & 1-6.P.96-97 \\
\hline & Fred's things & 18-19 & 1-5.P.98-99 \\
\hline & REVIEW & $20-21$ & \\
\hline \multirow{4}{*}{$\begin{array}{l}\text { AROUND } \\
\text { SCHOOL }\end{array}$} & $\begin{array}{l}\text { The } \\
\text { school }\end{array}$ & $22-23$ & 1-5.P.100-101 \\
\hline & What's it like? & $24-25$ & 1-5.P.102-103 \\
\hline & $\begin{array}{l}\text { Vision 2030: A new } \\
\text { club }\end{array}$ & $26-27$ & 1-5.P104-105 \\
\hline & REVIEW & $28-29$ & \\
\hline \multirow{4}{*}{ WHEN IS IT? } & What's the time? & 30-31 & 1-4.P.106-107 \\
\hline & Can you help us? & $32-33$ & 1-5.P.108-109 \\
\hline & In winter it's cold & 34-35 & 1-5.P.110-111 \\
\hline & REVIEW & 36-37 & \\
\hline \multirow{4}{*}{$\begin{array}{l}\text { FOOD } \\
\text { MEALS }\end{array}$} & We'd love to & 38-39 & 1-6.P.112-113 \\
\hline & It smells good & $40-41$ & 1-5.P.114-115 \\
\hline & $\begin{array}{l}\text { What's this in } \\
\text { English? }\end{array}$ & $42-43$ & 1-5.P.116-117 \\
\hline & REVIEW & & \\
\hline \multirow{4}{*}{ HOT AND COLD } & What's the matter & 46-47 & 1-6.P.118-119 \\
\hline & $\begin{array}{l}\text { Weekdays and } \\
\text { weekends }\end{array}$ & 48-49 & 1-4.P.120-121 \\
\hline & The weather & $50-51$ & 1-4.P.122-123 \\
\hline & REVIEW & $52-53$ & \\
\hline \multirow{4}{*}{$\begin{array}{l}\text { GOING TO THE } \\
\text { MALL }\end{array}$} & Your house at 6 & $54-55$ & 1-40.P.124-125 \\
\hline & It's so expensive & $56-57$ & 1-5.P.126-127 \\
\hline & A menu in English & $58-59$ & 1-5.P.128-129 \\
\hline & REVIEW & $60-61$ & \\
\hline \multirow{4}{*}{$\begin{array}{l}\text { I'M SORRY I'M } \\
\text { LATE }\end{array}$} & My watch is wrong & $62-63$ & 1-6.P.130-131 \\
\hline & $\begin{array}{l}\text { A DVD about } \\
\text { Oxford }\end{array}$ & $64-65$ & 1-7.P.132-133 \\
\hline & $\begin{array}{l}\text { I was asleep on the } \\
\text { bus }\end{array}$ & $66-67$ & 1-5.P.134-135 \\
\hline & REVIEW & 68-69 & \\
\hline \multirow{4}{*}{$\begin{array}{lc}\text { BAD } & \text { TIMES } \\
\text { GOOD TIMES }\end{array}$} & I wasn't very well & $70-71$ & 1-6.P.136-137 \\
\hline & Top of the class & $72-73$ & 1-6.P.138-139 \\
\hline & All about Jeddah & $74-75$ & 1-6.P.140-141 \\
\hline & REVIEW & 76-77 & \\
\hline \multirow{4}{*}{ TIME TO GO } & Picnic time & 78-79 & 1-5.P.142-143 \\
\hline & Follow me & $80-81$ & 1-6.P.144-145 \\
\hline & Nina's present & $82-83$ & 1-6.P.146-147 \\
\hline & REVIEW & $84-85$ & \\
\hline
\end{tabular}




\section{Instrument of the study:}

The study instrument consisted of a list of critical thinking skills prepared by the researcher, after reviewing several previous studies related to critical thinking and educational literature that dealt with these skills. A content analysis form was dessigned that included five main skills as follows:

- Recognition of assumption skill, it includes (3) sub-skills namely: recognizing, examination of facts, and the formulation of hypotheses.

- Interpretation skill, it includes (5) sub-skills namely: explanation, classification, defining, discovery, and comprehension.

- Deduction skill, it includes (4) sub-skills, namely: discrimination, access to evidence, evaluation, and identification.

- Inference skill, it includes two sub-skills, namely: judging, and recognizing relations.

- Evaluation of arguments Skill, it includes (3) sub-skills namely: clarification, analysis, and research

Validity of the instrument:

To verify the validity of the instrument, it was presented to a jury of professors of curriculum and methods of teaching English. The necessary modifications were done and the analysis form was modified according to the observations of the jury; some jury also suggested a criterion for judging availability of Critical Thinking Skills In the first grade English language course. It was that main skills achieve $15 \%$ and 5\% for sub-skills.

\section{Reliability of the instrument:}

The reliability of the content analysis form was calculated by inter-personal method to achieve relatively close results using the same analysis form. Another expert in the same field and has experience in teaching. 


\section{Procedures:}

A list of critical thinking skills analysis was prepared by reference to previous studies and theoretical literature related to critical thinking skills. The researcher designed the analysis form and presented it in its preliminary form to the jury to verify the validity of the tool.

- The community and sample of the study have also been identified.

- Scheduling and organizing the units of the book and the lessons and activities included in each unit and determining the page numbers.

- After the analysis process, statistical processing adopted for this study was applied.

\section{Statistical Processing:}

Calculating frequencies and percentages, and the degree of agreement between the researcher and the observer on the previous results

Table (2): Number and percentages of ideas and exercises that included critical thinking skills in English textbook for the first intermediate grade and the degree of agreement between the researcher and the observer distributed by unit

\begin{tabular}{|c|c|c|c|c|c|c|c|c|c|c|}
\hline \multirow[t]{2}{*}{ Unit } & \multicolumn{5}{|c|}{ The idea that included critical thinking skills } & \multicolumn{5}{|c|}{ Exercises included critical thinking skills } \\
\hline & $\begin{array}{l}\mathbf{1}^{\text {st }} \\
\mathbf{O}\end{array}$ & Percent & $\begin{array}{l}2^{\text {nd }} \\
O\end{array}$ & Percent & Agreement & $\begin{array}{l}1^{\text {st }} \\
\mathbf{O}\end{array}$ & Percent & $\begin{array}{l}2^{\text {nd }} \\
O\end{array}$ & Percent & Agreement \\
\hline First & 26 & $10 \%$ & 27 & $10 \%$ & $96 \%$ & 11 & $12 \%$ & 11 & $12 \%$ & $100 \%$ \\
\hline Second & 27 & $10 \%$ & 28 & $11 \%$ & $96 \%$ & 6 & $6 \%$ & 8 & $9 \%$ & $75 \%$ \\
\hline Third & 26 & $10 \%$ & 21 & $8 \%$ & $81 \%$ & 7 & $7 \%$ & 5 & $5 \%$ & $71 \%$ \\
\hline Fourth & 23 & $9 \%$ & 24 & $9 \%$ & $96 \%$ & 8 & $8 \%$ & 8 & $9 \%$ & $100 \%$ \\
\hline Fifth & 24 & $9 \%$ & 24 & $9 \%$ & $100 \%$ & 8 & $8 \%$ & 8 & $9 \%$ & $100 \%$ \\
\hline Sixth & 18 & $7 \%$ & 17 & $6 \%$ & $94 \%$ & 15 & $16 \%$ & 10 & $11 \%$ & $67 \%$ \\
\hline Seventh & 29 & $11 \%$ & 29 & $11 \%$ & $100 \%$ & 5 & $5 \%$ & 8 & $9 \%$ & $63 \%$ \\
\hline Eighth & 24 & $9 \%$ & 27 & $10 \%$ & $89 \%$ & 12 & $13 \%$ & 12 & $13 \%$ & $100 \%$ \\
\hline Ninth & 36 & $13 \%$ & 35 & $13 \%$ & $97 \%$ & 13 & $14 \%$ & 13 & $14 \%$ & $100 \%$ \\
\hline Tenth & 36 & $13 \%$ & 34 & $13 \%$ & $94 \%$ & 10 & $11 \%$ & 8 & $9 \%$ & $80 \%$ \\
\hline Total & 269 & $100 \%$ & 266 & $100 \%$ & $99 \%$ & 95 & $100 \%$ & 91 & $100 \%$ & $96 \%$ \\
\hline
\end{tabular}


Table (2) clarifies that the total degree of agreement about the ideas that included critical thinking skills in the first intermediate grade for all units was $99 \%$ for both the researcher and the observer. The percentage of the degree of agreement for exercises that included critical thinking skills is $96 \%$.

It also clarifies that the highest percentages of the degree of agreement on the idea, which included critical thinking skills, related to the two units: the fifth and seventh; where the percentage reached $100 \%$ for both researcher and observer. The lowest of these percentages was the share of the third unit, where the percentage of agreement was $81 \%$, followed by the percentage of agreement for the eighth unit, which reached $89 \%$.

As for the exercises that included critical thinking skills, it is shown in Table (5) that the highest percentages of the degree of agreement on the exercises that included critical thinking skills were for the units: first, fourth, fifth, eighth and ninth; this percentage reached $100 \%$ for both the researcher and the ob5server. The lowest percentage was the share of the seventh unit, where the percentage was $63 \%$, followed by $r$ the sixth unit, which reached $67 \%$.

The researcher and the observer also have analyzed the content of the English language course for the first grade to determine the degree of agreement on the ideas that included critical thinking skills according to skill and unit as shown in Table (3).

Table (3) clarifies that the highest percentages of the degree of agreement of ideas that included critical thinking skills in the English textbook for the first intermediate grade by skill were the Evaluation of arguments, and Inference; the degree of agreement reached $100 \%$. The degree of agreement for the skill of deduction placed second with $98 \%$. Recognition of assumption placed third with $94 \%$ of agreement. In the last place, came interpretation skill with $91 \%$. 
Table (3): Number and percentages of ideas that included critical thinking skills in English textbook for the first intermediate grade and the degree of agreement between the researcher and the observer distributed by unit

\begin{tabular}{|c|c|c|c|c|c|c|c|c|c|c|c|c|c|c|c|}
\hline \multirow[t]{2}{*}{ Units } & \multicolumn{3}{|c|}{$\begin{array}{l}\begin{array}{l}\text { Recognition of } \\
\text { assumption }\end{array} \\
\end{array}$} & \multicolumn{3}{|c|}{ Interpretation } & \multicolumn{3}{|c|}{ Deduction } & \multicolumn{3}{|c|}{ Inference } & \multicolumn{3}{|c|}{$\begin{array}{l}\text { Evaluation of } \\
\text { arguments }\end{array}$} \\
\hline & $\begin{array}{l}1^{\text {st }} \\
\text { O }\end{array}$ & $\begin{array}{l}2^{\text {nd }} \\
0\end{array}$ & $\%$ & $\begin{array}{l}1^{\text {st }} \\
\text { O }\end{array}$ & $\begin{array}{l}2^{\text {nd }} \\
0\end{array}$ & $\%$ & $\begin{array}{l}1^{\text {st }} \\
0\end{array}$ & $\begin{array}{l}2^{\text {nd }} \\
0\end{array}$ & $\%$ & & & & & & $1^{\text {st }} \mathrm{O}$ \\
\hline First & 8 & 8 & $100 \%$ & 6 & 6 & $100 \%$ & 7 & 8 & $88 \%$ & 2 & 2 & $100 \%$ & 3 & 3 & $100 \%$ \\
\hline second & 3 & 3 & $100 \%$ & 7 & 8 & $88 \%$ & 7 & 7 & $100 \%$ & 4 & 4 & $100 \%$ & 6 & 6 & $100 \%$ \\
\hline Third & 1 & 1 & $100 \%$ & 9 & 4 & $44 \%$ & 7 & 7 & $100 \%$ & 3 & 3 & $00 \%$ & 6 & 6 & $100 \%$ \\
\hline Fourth & 2 & 2 & $100 \%$ & 9 & 9 & $100 \%$ & 5 & 5 & $100 \%$ & 5 & 5 & $100 \%$ & 2 & 3 & $67 \%$ \\
\hline Fifth & 2 & 2 & $100 \%$ & 9 & 9 & $100 \%$ & 4 & 4 & $100 \%$ & 4 & 4 & $100 \%$ & 5 & 5 & $100 \%$ \\
\hline Sixth & 1 & 1 & $100 \%$ & 6 & 5 & $83 \%$ & 3 & 3 & $100 \%$ & 5 & 5 & $100 \%$ & 3 & 3 & $100 \%$ \\
\hline Seventh & 1 & 1 & $100 \%$ & 12 & 12 & $100 \%$ & 4 & 4 & $100 \%$ & 8 & 8 & $100 \%$ & 4 & 4 & $100 \%$ \\
\hline Eighth & 4 & 5 & $80 \%$ & 4 & 4 & $100 \%$ & 7 & 7 & $100 \%$ & 3 & 4 & $75 \%$ & 6 & 6 & $100 \%$ \\
\hline Ninth & 2 & 2 & $100 \%$ & 10 & 8 & $80 \%$ & 8 & 9 & $89 \%$ & 7 & 7 & $100 \%$ & 9 & 9 & $100 \%$ \\
\hline tenth & 8 & 9 & $89 \%$ & 8 & 8 & $100 \%$ & 3 & 2 & $67 \%$ & 10 & 9 & $90 \%$ & 7 & 6 & $86 \%$ \\
\hline Total & 32 & 34 & $94 \%$ & 80 & 73 & $91 \%$ & 55 & 56 & $98 \%$ & 51 & 51 & $100 \%$ & 51 & 51 & $100 \%$ \\
\hline
\end{tabular}

All units related to recognition of assumptions skill obtained $100 \%$ of the degree of agreement except the units: tenth and eighth, the tenth unit received $89 \%$, and the eighth $80 \%$ of the degree of agreement with both the researcher and assistant. As for the skill of interpretation, six units received $100 \%$ of the degree of agreement of both the researcher and the assistant. The third unit received $44 \%$ of the degree of agreement, the ninth unit $80 \%$, the sixth unit $83 \%$, and the second unit $88 \%$

With regard to the skill of deduction, seven units obtained $100 \%$ of the degree of agreement for both the researcher and the observer. The tenth unit had $67 \%$ of the degree of agreement, the first unit $88 \%$ and the ninth unit $89 \%$. As for evaluation of arguments skill, eight units obtained $100 \%$ of the degree of agreement for both the researcher and the observer. The eighth unit obtained $75 \%$ of the agreement and the tenth unit obtained $90 \%$. As for the inference skill, eight units obtained $100 \%$ of the degree of agreement for both the researcher and the observer, while the fourth unit obtained $67 \%$ of the degree of agreement, and the tenth unit obtained $86 \%$. 
Moreover, the researcher and the observer analyzed the content of the English language course for the first intermediate grade to determine the degree of agreement on the exercises that included critical thinking skills by skill and unit as shown in Table (4).

Table (4) the degree of agreement on the exercises that included critical thinking skills by skill and unit

\begin{tabular}{|c|c|c|c|c|c|c|c|c|c|c|c|c|c|c|c|}
\hline \multirow[t]{2}{*}{ Units } & \multicolumn{3}{|c|}{$\begin{array}{l}\text { Recognition of } \\
\text { assumption }\end{array}$} & \multicolumn{3}{|c|}{ Interpretation } & \multicolumn{3}{|c|}{ Deduction } & \multicolumn{3}{|c|}{ Inference } & \multicolumn{3}{|c|}{$\begin{array}{ll}\text { Evaluation } & \text { of } \\
\text { arguments } & \\
\end{array}$} \\
\hline & $\begin{array}{l}1^{\text {st }} \\
\text { O }\end{array}$ & $\begin{array}{l}2^{\text {nd }} \\
0\end{array}$ & $\%$ & $\begin{array}{l}1^{\text {st }} \\
\mathbf{O}\end{array}$ & $\begin{array}{l}2^{\text {nd }} \\
0\end{array}$ & $\%$ & $\begin{array}{l}1^{\text {st }} \\
\text { O }\end{array}$ & $\begin{array}{l}2^{\text {nd }} \\
0\end{array}$ & $\%$ & & & & & & $1^{\text {st }} \mathrm{O}$ \\
\hline First & 3 & 2 & $67 \%$ & 3 & 3 & $100 \%$ & 2 & 2 & $100 \%$ & $\mathbf{0}$ & 1 & $0 \%$ & 3 & 3 & $100 \%$ \\
\hline second & 2 & 3 & $67 \%$ & 1 & 1 & $100 \%$ & 2 & 2 & $100 \%$ & 1 & 2 & $50 \%$ & 0 & 0 & $100 \%$ \\
\hline Third & 0 & $\mathbf{0}$ & $100 \%$ & 3 & $\mathbf{0}$ & $0 \%$ & 1 & 2 & $50 \%$ & 1 & 1 & $100 \%$ & 2 & 2 & $100 \%$ \\
\hline Fourth & 1 & 1 & $100 \%$ & 2 & 2 & $100 \%$ & 2 & 2 & $100 \%$ & 2 & 2 & $100 \%$ & 1 & 1 & $100 \%$ \\
\hline Fifth & 1 & 1 & $100 \%$ & 2 & 2 & $100 \%$ & 1 & 1 & $100 \%$ & 2 & 2 & $100 \%$ & 2 & 2 & $100 \%$ \\
\hline Sixth & 2 & 2 & $100 \%$ & 4 & 4 & $100 \%$ & 0 & $\mathbf{0}$ & $100 \%$ & 3 & 3 & $100 \%$ & 1 & 1 & $100 \%$ \\
\hline Seventh & 1 & 1 & $100 \%$ & 1 & 1 & $100 \%$ & $\mathbf{0}$ & $\mathbf{0}$ & $100 \%$ & 1 & 2 & $50 \%$ & 2 & 4 & $\mathbf{5 0 \%}$ \\
\hline Eighth & 1 & 1 & $100 \%$ & 5 & 4 & $80 \%$ & 0 & $\mathbf{0}$ & $100 \%$ & 3 & 3 & $100 \%$ & 3 & 4 & $75 \%$ \\
\hline Ninth & 3 & 3 & $100 \%$ & 1 & $\mathbf{0}$ & $0 \%$ & 2 & 2 & $100 \%$ & 4 & 4 & $100 \%$ & 2 & 4 & $50 \%$ \\
\hline tenth & 2 & 2 & $100 \%$ & 1 & 1 & $100 \%$ & 2 & 1 & $\mathbf{5 0 \%}$ & 4 & 3 & $75 \%$ & 1 & 1 & $100 \%$ \\
\hline Total & 16 & 16 & $100 \%$ & 23 & 18 & $78 \%$ & 12 & 12 & $100 \%$ & 21 & 23 & $91 \%$ & 17 & 22 & $77 \%$ \\
\hline
\end{tabular}

Table (4) clarifies that the highest percentages of the degree of agreement of exercises that included critical thinking skills in the English textbook for the first intermediate grade by skill were the Recognition of assumption, and deduction; the degree of agreement obtained $100 \%$. The degree of agreement for Evaluation of arguments skill placed second with 91\%. Interpretation skill placed third with $78 \%$ of agreement. In the last place, came inference skill with $77 \%$.

All units related to recognition of assumption skill obtained $100 \%$ of the degree of agreement except the units: first and second, they both got $67 \%$ of the degree of agreement for both the researcher and observer. As for the skill of interpretation, seven units reached $100 \%$ of agreement for both the researcher and the observer. The third and ninth had no agreement, the eighth unit $80 \%$. 
With regard to the skill of deduction, eight units obtained $100 \%$ of the degree of agreement for both the researcher and the observer. The third and tenth units had $50 \%$ of the degree of agreement, As for evaluation of arguments skill, six units obtained $100 \%$ of the degree of agreement for both the researcher and the observer. The first unit had no agreement; the second and seventh units obtained $50 \%$, while the tenth unit had $75 \%$. As for the inference skill, seven units obtained $100 \%$ of the degree of agreement for both the researcher and the observer, while the seventh and ninth units reached $50 \%$ of the degree of agreement, and the tenth unit obtained $75 \%$.

\section{Findings and discussion:}

Findings related to the second question: To what extent do critical thinking skills -in the English language for the first intermediate grade - exist?

To find out the availability of critical thinking skills in the English language course for the first intermediate grade, the researcher analyzed the course in light of critical thinking skills list, which she prepared, the following is the results of the analysis:

Table (5) shows the main critical thinking skills in the first intermediate grade English language course and their frequencies, percentage and ranks

\begin{tabular}{|c|l|c|c|c|}
\hline No. & Skill & Frequencies & Percentage & Rank \\
\hline 1 & Interpretation & 103 & $28.8 \%$ & 1 \\
\hline 2 & $\begin{array}{l}\text { Evaluation of } \\
\text { arguments }\end{array}$ & 72 & $20 \%$ & 2 \\
\hline 3 & Inference & 68 & $19 \%$ & 3 \\
\hline 4 & Deduction & 67 & $18.7 \%$ & 4 \\
\hline 5 & $\begin{array}{l}\text { Recognition of } \\
\text { assumption }\end{array}$ & 48 & $13.5 \%$ & 5 \\
\hline Total & & 358 & $100 \%$ & \\
\hline
\end{tabular}

It is noted from the previous table (5) that the interpretation skill got the highest percentage (28.8\%), followed by evaluation 
of arguments skill which ranked second with (20\%), Inference skill came in the third rank by (19\%), The deduction skill got the fourth rank (18.7\%). Recognition of assumptions skill came in the last rank by $(13.5 \%)$.

It is noticeable that the percentages among the main critical thinking skills in the first intermediate grade course are very close, consistent with Abu Mahdi's study (2011). This suggests that key critical thinking skills are not sufficiently available, especially as middle school students are weak in mastering critical thinking skills as (Zahrani, 2018) noted.

Table (6) shows critical thinking sub-skills in light of interpretation skill for the first intermediate grade English language course and their frequencies, percentage and ranks

\begin{tabular}{|c|l|c|c|c|}
\hline No. & $\begin{array}{l}\text { Sub-skills of } \\
\text { Interpretation }\end{array}$ & Frequencies & Percentage & Rank \\
\hline 1 & Comprehension & 103 & $54.4 \%$ & 1 \\
\hline 2 & Discovery & 72 & $24.3 \%$ & 2 \\
\hline 3 & Classification & 68 & $11.7 \%$ & 3 \\
\hline 4 & Explanation & 67 & $5.8 \%$ & 4 \\
\hline 5 & Defining & 48 & $3.8 \%$ & 5 \\
\hline Total & & 103 & $100 \%$ & \\
\hline
\end{tabular}

The previous table (6) clarifies that critical thinking subskills of interpretation skills were ranked as follows: "comprehension skill" came first with (54.4\%), followed by "discovery skill" with (42.3\%) then "classification skill" came third by (11.7). and fourthly came "explanation skill" with (5.8\%), "Recognition" came last by (3.8\%).

This indicates that the sub-skills of interpretation skills are not well available. This may be attributed to the lack of organization in the distribution of critical thinking skills in the English language course for the first intermediate grade according to characteristics of students at this stage as indicated by (Zahrani, 2018)and (Dulaimi and Huaymil, 2017). 
Table (7) shows critical thinking sub-skills in light of Evaluation of arguments skill for the first intermediate grade English language course and their frequencies, percentage and ranks

\begin{tabular}{|c|l|c|c|c|}
\hline No. & $\begin{array}{l}\text { Sub-skills of Evaluation of } \\
\text { arguments }\end{array}$ & $\begin{array}{c}\text { Frequenci } \\
\text { es }\end{array}$ & $\begin{array}{c}\text { Percenta } \\
\text { ge }\end{array}$ & $\begin{array}{c}\text { Ran } \\
\text { k }\end{array}$ \\
\hline 1 & Research & 29 & $\mathbf{4 0 . 3 \%}$ & $\mathbf{1}$ \\
\hline 2 & Clarification & 22 & $\mathbf{3 0 . 6 \%}$ & $\mathbf{2}$ \\
\hline 3 & analysis & $\mathbf{2 1}$ & $\mathbf{2 9 . 1 \%}$ & $\mathbf{3}$ \\
\hline Total & & $\mathbf{7 2}$ & $\mathbf{1 0 0 \%}$ & \\
\hline
\end{tabular}

The previous table (7) clarifies that critical thinking subskills of Evaluation of arguments skills were ranked as follows: "research skill" came first with (40.3\%), followed by "discovery skill" with (30.6\%), "analysis" came last by (3.8\%).

Table (8) shows critical thinking sub-skills in light of inference skill for the first intermediate grade English language course and their frequencies, percentage and ranks

\begin{tabular}{|c|l|c|c|c|}
\hline No. & Sub-skills of inference & Frequencies & Percentage & Rank \\
\hline 1 & recognizing relations & 42 & $61.8 \%$ & 1 \\
\hline 2 & Judging & 26 & $38.2 \%$ & 2 \\
\hline Total & & 68 & $100 \%$ & \\
\hline
\end{tabular}

The previous table (8) clarifies that critical thinking subskills of inference skills were ranked as follows: " recognizing relations skill" came first with (61.8\%), followed by "judging skill" with (38.2\%).

Table (9) shows critical thinking sub-skills in light of deduction skill for the first intermediate grade English language course and their frequencies, percentage and ranks

\begin{tabular}{|c|l|c|c|c|}
\hline No. & Sub-skills of deduction & Frequencies & Percentage & Rank \\
\hline 1 & Discrimination & 32 & $47.8 \%$ & 1 \\
\hline 2 & Identification & 22 & $32.8 \%$ & 2 \\
\hline 3 & access to evidence & 7 & $10.4 \%$ & 3 \\
\hline 4 & Assessment & 6 & $9 \%$ & 4 \\
\hline Total & & 67 & $100 \%$ & \\
\hline
\end{tabular}

The previous table (9) clarifies that critical thinking subskills of interpretation skill were ranked as follows: discrimination skill" came first with (47.8\%), followed by " 
identification skill" with (32.2\%) then " access to evidence skill" came third by (10.4). and fourthly came "assessment skill" with (9\%).

This indicates that the sub-skills of the deduction skill vary, while "discrimination skill" obtained the highest percentage (47.8\%), the "assessment skill" obtained the lowest percentage (9\%). These findings are consistent with the findings of the (geek,2009) which indicates that there are some Sub-skills are neglected in school curricula.

Table (10) shows critical thinking sub-skills in light of Recognition of assumption skill for the first intermediate grade English language course and their frequencies, percentage and ranks

\begin{tabular}{|c|l|c|c|c|}
\hline No. & $\begin{array}{l}\text { Sub-skills of Recognition of } \\
\text { assumption }\end{array}$ & Frequencies & Percentage & Rank \\
\hline 1 & Authenticity & 22 & $45.8 \%$ & 1 \\
\hline 2 & examination of facts & 20 & $41.7 \%$ & 2 \\
\hline 3 & formulation of hypotheses & 6 & $12.5 \%$ & 3 \\
\hline Total & & 48 & $100 \%$ & \\
\hline
\end{tabular}

The previous table (10) clarifies that critical thinking subskills of recognition of assumption skill were ranked as follows: " Authenticity skill" came first with (45.8\%), followed by " examination of facts skill" with (41.7\%) then " formulation of hypotheses skill" came third by (12.5).

This indicates that the sub-skills of the recognition of assumptions skill are well available. However, it is noticeable that they vary in the distribution of skills, where Authenticity skill obtained (45.8\%), the formulating hypotheses skill obtained $(12.5 \%)$.

\section{Conclusion and recommendations}

In short, findings indicate that there is variance among percentages of the main critical thinking skills and the sub-skills in the first intermediate grade English language course. Findings also reveal that the English course for the first intermediate grade lacks balance between the main skills of critical thinking and sub-skills, especially that the sub-skills complement the 
main skills, and the sub-skills of critical thinking are important, but they do not achieve learning critical thinking needed to be learned.

\section{The current study recommends:}

1. Reconsider-during the development of the English language course for the first intermediate grade process- concentrating on critical thinking skills in line with the requirements of the current age, and paying attention to students at this stage in particular; since it is a stage of the development of tendencies and interests, and the emergence of interest in academic and career future, and tendency to critical thinking since no acceptance for facts without evidence.

2. The authors of English language courses -for the first intermediate grade- should concentrate on the importance of developing critical thinking system in the content of the course, and design a content focused on motivating these skills. They also should consult teachers and supervisors of the English language for the middle school during the process of selecting and designing content that meets the requirements of this type of thinking.

\section{References:}

- Abu Mahadi, Saber Abdulkareem (2011). Critical thinking skills included in physics for secondary school and the extent of students' acquisition, Islamic University of Gaza, Faculty of Education, an unpublished master thesis.

- Abu Qattam, Muslim Fouad and Al-Khawaledah, Ahmed Hamad (2008). The focus of the official English language curricula for the seventh and eighth grades on critical and creative thinking skills. Ph.D. University of Jordan- Faculty of Education, Oman.

- Al-Ajmi, Maha Mohammed (2005). curricula: foundations, components, organizations, and educational applications: an educational vision combining the Western and Islamic perspective of the curriculum, $2^{\text {nd }}$ edition. 
- Al-Atabi, Mohammed Ishaq (1966). How to learn a foreign language? The message of the teacher, vol. 9, No. 3-4, Ministry of Education.

- Al-Atoum, Adnan and Jarrah, Abdul Nasser and Bashara, Mowaffaq (2011). Development of thinking skills, $3^{\text {rd }}$ edition, Oman, Dar Al-Masirah.

- Al-Dulaimi, Iyad and Al-Huwaimel, Omar (2018). Critical Thinking Skills Included in the Eighth Grade Arabic Textbook in Jordan, Descriptive and Analytical Study. Journal of Islamic University for Educational and Psychological Studies, Vol. 3, No. 26. Zagazig.

- Al-Falabi, Ibrahim Saleh (1995). The Relationship between English Skills: A Holistic Perspective for Teaching English as a Foreign Language, Journal of Education, Vol. 24, No. 114.

- Al-Khalifa, Hassan Jafar (2015). Introduction to Curricula and Teaching Methods, Al-Rashed Library, Riyadh, 10th edition.

- Al-Mahoos, Walid Ibrahim (2009). the extent to which the third grade grammar books contain critical thinking skills, Journal of the Faculty of Education in Zagazig, No. 64.

- Al-Moagam Al-Waseet: The Arabic Language center in Cairo (Ibrahim Mostafa / Ahmed El-Zayyat / Hamed Abdel-Kader / Mohammad Al-Najjar) Publisher: Dar Al-Da'wa.

- Al-Mubadil, Abdulmohsen Bin Rasheed (2010), The Positive Components of the Environmental Classroom -in the Light of Murray's Theory- and its Relationship with Critical Thinking Skills. A Field Study on High School Students in Riyadh, Ph.D Thesis, Imam Muhammad Bin Saud University.

- Al-Nafi, Abdullah (2008). Teaching Thinking in the Arab World: A Proposed Strategic Plan. The second Arab Meeting for Teaching Thinking and Developing Creativity, Domino Center for Teaching Thinking.

- Al-Qutaiti, Mohammed Hamad (2016). Critical Thinking and its implications in School, Reading and Knowledge Magazine. Vol. 176, Egyptian Association for Reading and Knowledge.

- Al-Rajhi, Hamad Bin Salem (2008). Developing Higher Thinking abilities and Skills for Students in the Curriculum in the Amman Region: The Second Arab Meeting for Teaching Thinking and Developing Creativity. 
- Al-Wakeel, Helmi, \& Al-Mufti, Mohammed Amin (2005). Principles of Curriculum Building and designing, Dar Al-Masira, Oman.

- Al-Zahrani, Khalid bin Saeed (2018). The extent of the ability of the first grade students in Jeddah, Saudi Arabia, of critical thinking skills in mathematics, Journal of Educational and Psychological Sciences, Vol. 2, No. 12.

- Bajamil, Issam Zakaria (2011). Reasoning and Critical Thinking, Amman, Al-Masirah Publishing House.

- Facione m P.A (2010): Critical thinking what it is and why it count, Millbrae, CA: Calfornia.

- Facione m P.A (2010): Critical thinking what it is and why it count, Millbrae, CA: Calfornia.

- Fitcher, Alk (2009). Critical Thinking, Dar Al-Sayed for Publishing, translation by: Yasser Al-Otaibi, Mohammed bin Rashid Al Maktoum Organization.

- Garwan, Fathi Abdulrahman (2004). Teaching thinking: concepts and applications, Journal of Education, Vol. 33, No. 151.

- Mokhtar, Ehab Ahmed (2014), an analytical study of the role of science courses in developing scientific thinking and critical thinking skills and the interaction between sex variables and geographical location of secondary school students, the Egyptian Journal of field Education, vol 17, p 34, Egyptian Association for Field Education.

- Nawafleh, Walid (2015). Critical Thinking Skills Included in the Questions Content of the Chemistry Books for the 9th and 10th Basic Grades in Jordan, Al-Manara Journal for Research and Studies, Vol. 21, No. 4, A.

- Sahou, Siham Abdel-Nabi (2017). Teaching with Adi and Shire Model and its Effect on Achievement and Critical Thinking of First Grade Intermediate Students in Mathematics, Journal of Educational and Psychological Research, Issue: 54.

- Saleh, Ahmed Zaki (1992). Educational Psychology, Dar AlMaarif, Cairo, $16^{\text {th }}$ edition.

- Swaid, Abdel-Moaty (2005). Thinking skills and face of life, University Book House, Alexandria, Egypt.

- Zahran, Hamid Abdelsalam (2005), Childhood and Adolescent Psychology, 6th edition, Cairo: Science of Books. 